\title{
THE PROMOTION OF EQUALITY AND PREVENTION OF UNFAIR DISCRIMINATION ACT 4 OF 2000: PROPOSALS FOR LEGISLATIVE REFORM
}

\author{
ANTON KoK ${ }^{*}$
}

\begin{abstract}
This article considers the limits of the law in addressing discrimination. It discusses to what extent the Promotion of Equality and Prevention of Unfair Discrimination Act 4 of 2000 will achieve its stated goals of facilitating socio-economic transformation, facilitating the creation of a more caring society, and establishing accessible enforcement mechanisms. It then identifies a number of provisions in the Equality Act that could have been drafted more carefully in service to these goals. It, inter alia, suggests that the definition of 'discrimination' in the Act be added to; that the list of prohibited grounds in the Act be extended; that systemic discrimination be addressed much more explicitly; and that s 14 be refined.
\end{abstract}

\section{INTRODUCTION}

Since the first democratic elections in 1994, the South African government has attempted to counter a legacy of grossly unequal allocation of resources, wealth and power. One of the most important in a string of legislative attempts to undo the effect of centuries of race-based oppression and marginalisation (including, obviously, apartheid) was the Promotion of Equality and Prevention of Unfair Discrimination Act 4 of 2000 (The Equality Act).

As an example of 'anti-discrimination legislation', the Act is ambitious in scope. It outlaws unfair discrimination in almost every sphere of society ${ }^{1}$ and also aims at preventing and prohibiting harassment ${ }^{2}$ and hate speech. ${ }^{3}$ In addition, the Act entrenches positive duties in respect of equality by calling on the state and all persons to promote substantive equality. ${ }^{4}$

This article has the following structure. In section II, I briefly discuss the typical 'defects' in anti-discrimination legislation and how the

* Senior Lecturer, Faculty of Law, University of Pretoria. This article is largely based on relevant parts of my doctoral thesis titled 'A Socio-legal Analysis of the Promotion of Equality and Prevention of Unfair Discrimination Act 4 of 2000'. I thank the anonymous SAJHR referees for their comments, which led to an improved article. All mistakes and omissions remain my own.

1 See the Schedule to the Act that contains an 'Illustrative list of unfair practices in certain sectors'. The Schedule to the Act 'is intended to illustrate and emphasise some practices which are or may be unfair, that are widespread and that need to be addressed' (read with s 29(1)).

2 Section 11 read with the definition of 'harassment' in s 1(xiii).

3 Section 10.

4 Section 24 read with the definition of 'equality' in s 1(1)(ix). This is limited for individuals in terms of ss 26 and 27. 
South African legislature attempted to deal with these when it drafted the Act. In section III, I discuss in more general terms why the law will likely remain a limited tool in addressing discrimination. I then move to specific proposals for reform in sections IV to IX. I inter alia suggest that the definition of 'discrimination' in the Act be added to; that the list of prohibited grounds in the Act be extended; that systemic discrimination be addressed much more explicitly; and that s 14 be refined.

\section{Typical Shortcomings of Anti-Discrimination Legislation AND HOW THe South African Legislature AdDressed them}

Based on academic writing from mainly Australia, Canada, the United Kingdom and the United States relating to discrimination law, I extracted the following typical defects in anti-discrimination legislation: It is notoriously difficult to prove a discrimination complaint; ${ }^{5}$ enforcement mechanisms are usually constrained by the range of remedies they are allowed to choose from, ${ }^{6}$ and are ill-equipped to deal with discrimination complaints as they may be under-resourced, or may have insufficient powers to fulfil their statutory obligations $;^{7}$ non-experts often chair tribunals; ${ }^{8}$ legal aid is not necessarily available to complainant; ${ }^{9}$ anti-discrimination Acts may allow a claim on only a limited number of grounds, ${ }^{10}$ anti-discrimination Acts may have a limited reach or area(s) of application; ${ }^{11}$ the use of a 'neutral' comparator hides societal

5 R Moon 'Discrimination and Its Justification: Coping with Equality Rights Under the Charter' (1988) 26 Osgoode Hall LJ 673, 687; Varney H 'Forging New Tools: A Note on Fose v Minister of Safety and Security CCT 14/96' (1998) 14 SAJHR 336, 346; N Lacey 'From Individual to Group?' in B Hepple \& EM Szyszczak (eds) Discrimination: The Limits of Law (1992) 99, 101; N Lacey 'Legislation Against Sex Discrimination: Questions from a Feminist Perspective' (1987) 14 Journal of Law and Society 411, 412; L Dickens 'Road Blocks on the Route to Equality: The Failure of Sex Discrimination Legislation in Britain' (1991) 18 Melbourne Univ LR 277, 285-7; P Bailey \& A Devereux 'The Operation of Anti-Discrimination Laws in Australia' in D Kinley (ed) Human Rights in Australian Law: Principles, Practice and Potential (1998) 292, 308; L De Plevitz 'The Briginshaw "Standard of Proof" in Anti-Discrimination Law: "Pointing with a Wavering Finger" (2003) 27 Melbourne Univ LR 308.

6 Dickens (note 5 above) 284-7; Lacey (note 5 above) 412; Lacey in Hepple and Szyszczak (note 5 above) 101; M Connolly Discrimination Law (2006) 395; IB McKenna 'A Proposal for Legislative Intervention in Canadian Human Rights Law' (1992) 21 Manitoba LJ 325.

7 Lacey in Hepple \& Szyszczak (note 5 above) 101; Lacey (note 5 above) 412; Dickens (note 5 above) 286-7.

$8 \quad$ Lacey in Hepple \& Szyszczak (note 5 above) 101; Lacey (note 5 above) 413.

$9 \quad$ Lacey (note 5 above) 413; Lacey in Hepple \& Szyszczak (note 5 above) 101; Dickens (note 5 above) 285-7; M Galanter 'Why the "Haves" Come out Ahead: Speculations on the Limits of Legal Change' (1974) 9 Law and Society Review 95, 114.

10 DG Réaume 'Of Pigeonholes and Principles: A Reconsideration of Discrimination Law' (2002) 40 Osgoode Hall LJ 113, 115, 124, 132; S Hannett 'Equality at the Intersections: The Legislative and Judicial Failure to Tackle Multiple Discrimination' (2003) 23 Oxford Journal of Legal Studies 65, 65, 69; MJ Zimmer 'Book Review: Equality: A New Framework — Report of the Independent Review of the Enforcement of UK Anti-Discrimination Legislation' (1999) 21 Comparative Labour Law and Policy Journal 249, 253.

11 Réaume (note 10 above) 124; Bailey \& Devereux (note 5 above) 297; Lacey in Hepple \& Szyszczak (note 5 above) 105. 
inequalities; ${ }^{12}$ some jurisdictions favour conciliation (and secrecy) over public court hearings, which could frustrate attempts to create a broader consciousness of discrimination; ${ }^{13}$ anti-discrimination provisions are generally enforced by a complaints-driven process and it is expected that complainants initiate the procedure, ${ }^{14}$ which means that if a complainant does not perceive that she has been discriminated against, she will obviously not approach a court or tribunal and the resultant harm or disadvantage will remain unaddressed. ${ }^{15}$

Perhaps the most serious 'defect' is that it is very hard to conceive of effective litigation strategies to combat structural discrimination. ${ }^{16}$ Structural discrimination is very difficult to attack, even if the concept of indirect discrimination is used, because an individual claim will likely be brought, ${ }^{17}$ with the hope that a successful outcome in one case will lead to ongoing effects. ${ }^{18}$ Coupled with this limitation is the underlying implication of an individual lawsuit that what is being complained about is somehow abnormal; out of the ordinary; while the 'truth' is that discrimination is the norm. ${ }^{19}$ A tribunal treating an individual complaint as an 'abnormality'; a tribunal that fails to

12 Cf Connolly (note 6 above) 63-7; P de Vos 'Sexual Orientation and the Right to Equality in the South African Constitution: National Coalition for Gay and Lesbian Equality v Minister of Justice (2000) 117 SALJ 17, 21; P de Vos 'Same-sex Marriage, the Right to Equality and the South African Constitution' (1996) 11 SAPL 355, 374; Dickens (note 5 above) 290; Hannett (note 10 above) 67 \& 82-3; Lacey (note 5 above) 417; Lacey in Hepple \& Szyszczak (note 5 above) 103 \& 107; O Prendeville 'Equality Legislation - A Success or Failure?' (1991) 1 Irish Student LR 21, 25; M Minow 'Stripped Down Like a Runner or Enriched by Experience: Bias and Impartiality of Judges and Jurors' (1992) 33 William and Mary LR 1201, 1207; W Baker 'Women's Diversity: Legal Practice and Legal Education - A View from the Bench' (1996) 45 Univ of New Brunswick LJ 199; C O'Regan 'Equality at Work and the Limits of the Law: Symmetry and Individualism in Anti-discrimination Legislation' 1994 Acta Juridica 64, 79; C Barnard \& B Hepple 'Substantive Equality' (2000) 59 Cambridge LJ 562, 563; M Thornton 'Comment on Linda Dickens' Road Blocks on the Road to Equality: The Failure of Sex Discrimination in Britain'(1991) 18 Melbourne Univ LR 298, 300 .

13 Bailey \& Devereux (note 5 above) 303.

14 R Pound 'The Limits of Effective Legal Action' (1917) 3 The American Bar Association Journal 55, 69 ('For laws will not enforce themselves. Human beings must execute them, and there must be some motive setting the individual in motion to do this above and beyond the abstract content of the rule and its conformity to an ideal justice or an ideal of social interest'); Dickens (note 5 above) 294; JF Handler Social Movements and the Legal System: A Theory of Law Reform and Social Change (1978) 103-18.

15 For example, E Millar \& J Phillips 'Evaluating Anti-discrimination Legislation in the UK: Some Issues and Approaches' (1983) 11 IJSL 417, 424 refer to research that have indicated that a minority of female employees perceives that discrimination is operating against them.

16 S Fredman 'Providing Equality: Substantive Equality and the Positive Duty to Provide' (2005) 21 SAJHR 163, 168. Also compare Fuller's discussion of 'polycentric problems' in R Fuller 'The Forms and Limits of Adjudication' (1978) 92 Harvard LR 353, and his view that courts are not suited to solving these kinds of problems.

17 Class actions or representative actions are few and far between in anti-discrimination litigation. Bailey \& Devereux (note 5 above) 301. Also see W Freedman 'Formal Versus Substantive Equality and the Jurisprudence of the Constitutional Court' (2000) 63 THRHR 314, 320 and W Freedman 'Understanding the Right to Equality' (1998) 115 SALJ 243, 251. (He argues that 'the adjudicative model is designed to deal with discrete wrongs and not with systemic inequality'.)

18 I Parghi 'A Blueprint for a Brighter Future: The Report of the Canadian Human Rights Act Review Panel' (2001) 13 Canadian Journal of Women and the Law 137, 144 argues that individual discrimination complaints that are expansively remedied can do a lot of systemic work.

19 Lacey (note 5 above) 417-8; Hannett (note 10 above) 86. 
understand that 'but that is how things are' is not a defence, will not effect real change. ${ }^{20}$ To put it bluntly, law cannot cope with an argument that 350 years of colonialism, patriarchy and apartheid have caused the current state of affairs in South Africa: Who must be sued? ${ }^{21}$ By whom? What is the cause of action? ${ }^{22}$

To their credit, the drafters of the Act did attempt to address the traditional defects of anti-discrimination legislation:

1. The Act embraces a substantive notion of equality. ${ }^{23}$

2. In contrast to many other anti-discrimination statutes, ${ }^{24}$ the Act does not expressly require a comparison between the complainant and a suitable comparator. ${ }^{25}$ It would therefore seem possible to base a claim on the mere fact that the complainant may be identified by one or more of the prohibited grounds, with the important proviso that the complainant must have suffered some identifiable harm. ${ }^{26}$

3. The Act contains an open list of prohibited grounds. In s 1(1)(xxii) a number of grounds are explicitly listed and the Act creates a test in terms of which additional grounds may be recognised by courts. Instead of having to follow the 'pigeon-hole' approach of, for example, the Canadian antidiscrimination jurisdictions, ${ }^{27}$ courts may of their own accord 'invent' or 'discover' new grounds that are worthy of protection and need not wait for legislative approval of the new ground. A discrimination complaint may

20 Lacey in Hepple \& Szyszczak (note 5 above) 102-3.

21 The law of delict offers a similar problem where a 'mass wrong' had occurred. Cf GE Marcus 'Mass Toxic Torts and the End of Everyday Life' in A Sarat \& TR Kearns (eds) Law in Everyday Life (1995) 237, 253: 'Throughout the twentieth-century history of torts, the most difficult cases have been those in which the connections between the injured and the injurers have been the most difficult to establish'.

22 B Hepple 'Equality Laws and Economic Efficiency' (1997) 18 ILJ 598, 604-5. Where an individual perpetrator may be identified, the remedy that a court will grant will probably only affect that individual perpetrator and not lead to ongoing, structural changes to society.

23 Section 1(1)(ix) of the Act.

24 For example, see s 10 of the Queensland Anti-Discrimination Act and s 8 of the Victoria Equal Opportunity Act. In Andrews v British Columbia [1989] 1 SCR 143 at 164 the Canadian Supreme Court opined that '[Equality] is a comparative concept, the condition of which may only be attained or discerned by comparison with the condition of others in the social and political setting in which the question arises'.

25 C Albertyn \& J Kentridge 'Introducing the Right to Equality in the Interim Constitution' (1994) 10 SAJHR 149, 153-5 point out that the 'similarly situated' test as developed in the United States and Canada is 'insufficient because it does not supply criteria by which to judge (a) when a person is similarly situated and with whom; (b) when a person should be treated in the same way, or differently; and (c) what kind of different treatment is appropriate'. Canadian courts have since developed a greater appreciation for targeting social, political and legal prejudice and vulnerability.

26 N Bohler-Muller \& M Tait 'The Equality Courts as a Vehicle for Legal Transformation - A Few Practical Suggestions' (2000) 21 Obiter 406, 410: 'Critical Legal Theorists demand that we deal with individuals in the context of their disadvantage and that equality issues have to address the actual conditions of human life' (my emphasis). (The Act refers explicitly to disadvantage and the complainant's context in the preamble, ss 3(1)(a), 4(2) and 14(2)(a).)

27 Réaume (note 10 above) 113 describes how the Ontario legislature followed this a approach in extending protection to different sectors and to different grounds. For example, race and religion were first identified, followed by 'colour, nationality, ancestry or place of origin', age in 1966, sex and marital status in 1972, family status and handicap in 1981, and sexual orientation in 1986. 
also be brought on 'one or more' prohibited grounds, which means that a complainant does not have to choose a particular ground on which to base her claim, and risk losing the case for choosing the 'wrong' ground. ${ }^{28}$

4. Compared to the usual principles that apply in civil cases, the Act substantially eases the complainant's evidentiary burden. Briefly put, the complainant must establish that 'discrimination' occurred on a prima facie basis. It is then up to the respondent to justify the discrimination as fair. ${ }^{29}$

5. At least on paper, the equality courts are accessible forums. Where a complainant is unrepresented, the clerk of the equality court is supposed to step into the breach and fulfil the role of a paralegal - the clerk must assist complainants in completing the forms and give elementary legal advice. ${ }^{30}$ The regulations explicitly attempt to create informal courts where substance is supposed to triumph over technicality. During the directions hearing, the presiding officer may make an order relating issues such as the discovery of documents, admission of facts or of documents; the manner of service of documents; amendments; the filing of affidavits and the giving of further particulars and is not required to deal with the matter in accordance with the ordinary, formal rules of court. The regulations envisage active, interventionist presiding officers who may dispense with the ordinary court rules and ordinary time limits in effecting justice. Presiding officers may of their own accord question witnesses and to this end the equality courts are allowed to act as inquisitorial institutions, similar to the Small Claims Courts. ${ }^{31}$ The regulations largely follow the ordinary rules of civil litigation as they relate to costs and the non-appearance of a particular party. The default option however seems to be that both parties should pay their own costs, instead of the position in ordinary civil litigation that the loser pays the winner's legal costs. The equality court presiding officer is allowed to depart from the default position - a vexatious complainant comes to mind. ${ }^{32}$ The regulations also envisage an active, interventionist presiding officer that may on her own initiative subpoena a person to appear as a witness at the hearing. ${ }^{33}$

6. The prohibition against unfair discrimination is not qualified in the Act in principle and on a strict literal interpretation the Act applies everywhere, anywhere and to all cases of 'private' and 'public' discrimination. The

Réaume (note 10 above) 133 refers to De Graffenreid v General Motors 413 F Supp 142 (ED Mo 1976) in which a black woman's discrimination complaint was dismissed, apparently on the basis that the respondent could show that he had hired black men and white women, which persuaded the court that neither race nor sex discrimination was present.

29 Section 13 of the Act. Also see A Kok 'Motor Vehicle Insurance, the Constitution and the Promotion of Equality and Prevention of Unfair Discrimination Act (2002) 18 SAJHR 59, 67-8 and A Kok 'The Promotion of Equality and Prevention of Unfair Discrimination Act: Why the Controversy?' (2001) Journal of South African Law 294, 300-4.

30 Regulation 5 of GN R764.

31 Regulation 10 of GN R764.

32 Regulation 10 of GN R764.

33 Regulation 8 of GN R764. 
Act contains no (sector-specific) exclusions or defences, only the general 'fairness' defence. ${ }^{34}$ Equality courts will have to develop principles over time as to what constitutes 'fair' discrimination in particular contexts. This allows much room for disgruntled complainants to argue that what had happened to them amounted to 'unfair' discrimination, even if the discrimination occurred in the private sphere.

7. Section 20 of the Act embraces a broad notion of standing and allows the following parties standing in an equality court: A complainant acting in his/her own interest; a complainant acting on behalf of another person who cannot act in their own name; a complainant acting as a member of or in the interests of a group or class of persons; a complainant acting in the public interest; an association acting in the interests of its members; and the South African Human Rights Commission and the Commission for Gender Equality.

8. The Constitutional Court in Fose v Minister of Safety \& Security ${ }^{35}$ implored courts to 'forge new tools' and 'shape innovative remedies' in the context of a country where extensive human rights violations have taken place and where few people have effective access to courts. ${ }^{36}$ The Act lists an extraordinary long (and open) list of explicit remedies that may be utilised by the equality courts, and empowers equality courts to make 'appropriate' orders. It includes interim and declaratory orders, payment for damages, interdicts, implementation of special measures, an unconditional apology, an order directing the reasonable accommodation of a group or class of persons, and an order requiring the respondent to undergo an audit of its policies or practices. ${ }^{37}$ This list of remedies should be read as an invitation to presiding officers to devise creative remedies to further the aims of the Act. There is no difference between the remedies that may be awarded by Magistrates' Courts and High Courts acting as equality courts.

In the next section, I discuss in general terms what the limits of the law are in combating discrimination.

\section{The Limits of the LAW IN AdDressing Discrimination ${ }^{38}$}

This part of the article contains four sections. In the first section, I discuss the ostensible purposes of anti-discrimination law. Thereafter I analyse two of these

By contrast, Australian and Canadian anti-discrimination legislation contains extensive exclusions (for example relating to religion and single-sex education) and defences. K Watkin 'The Justification of Discrimination under Canadian Human Rights Legislation and the Charter: Why So Many Tests?' (1992) 2 National Journal of Constitutional Law 63 laments the existence of four tests relating to justification under Canadian anti-discrimination law.

351997 (3) SA 786 (CC).

36 Para 69.

37 Section 21 of the Act.

38 Parts of this section also appear in A Kok 'The Promotion of Equality and Prevention of Unfair Discrimination Act 4 of 2000: Court-driven or Legislature-driven Societal Transformation?' (2008) 19 Stell LR 122 \& A Kok 'The Potential Effectiveness of the Promotion of Equality and Prevention of Unfair Discrimination Act 4 of 2000' (2008) 33 JJS (forthcoming). 
suggested purposes in more detail - the transformation of (South African) society and the establishment of accessible enforcement mechanisms. In the last section I consider to what extent the Act will achieve these purposes.

\section{(a) Suggested purposes of anti-discrimination law}

Anti-discrimination legislation could have a number of purposes:

(a) Parliament may wish to send a strong moral message that it views discrimination as an evil. Nothing more necessarily flows from the enactment of the law; the legislature may feel that its symbolic commitment to combating discrimination is sufficient. ${ }^{39}$

(b) The goal of an anti-discrimination Act could be to establish forums where discrimination complaints may be aired and resolved. ${ }^{40}$ This goal need not move much beyond a symbolic commitment: Such tribunals may not be properly resourced, or little publicity may be given to its existence, or to favourable outcomes for plaintiffs. ${ }^{41}$ At its most idealistic, the legislature may envisage that these forums will hear a large number of (individual) discrimination complaints and will resolve the complaints in favour of the plaintiffs. ${ }^{42}$

(c) The goal could be to achieve a thorough-going readjustment in income distribution and unemployment rates of various racial and ethnic groupings, so that these figures become proportionately equivalent to the most privileged group (usually whites). ${ }^{43}$

(d) At its most ambitious and idealistic, the legislature may wish to reach into the hearts, minds and homes of its subjects, and affect fundamental changes in basic social relationships. ${ }^{44}$

I would argue that the Act aims to achieve all these goals, but that the Act is primarily aimed at transforming South African society. I discuss my understanding of what 'transformative law' entails immediately below, whereafter I return to the goals of anti-discrimination legislation and the stated goals of the Act.

\section{(b) Transformative law}

As to what a transformative law entails, the literature is not clear. ${ }^{45}$ Authors that offer definitions, do so in rather general or even vague terms. Friedman

39 L Lustgarten 'Racial Inequality and the Limits of the Law' (1986) 49 Modern LR 68, 84-5; Lacey (note 5 above) 419-20.

40 Cf MK Joachim 'Reform of the Ontario Human Rights Commission' (1999) 13 Can J ALP 51, 52.

41 Bailey \& Devereux (note 5 above) 303.

42 L Lustgarten 'Racial Inequality, Public Policy and the Law: Where Are We Going?' in B Hepple \& EM Szyszczak (eds) Discrimination: The Limits of Law (1992) 455, 455-7 describes this goal as the 'just treatment of individuals'.

43 Ibid.

44 SBO Gutto Equality and Non-Discrimination in South Africa: The Political Economy of Law and Law Making (2001) 7.

45 R Cotterrell The Sociology of Law: An Introduction (1992) 47 puts it thus: 'It is clearly essential to try to pinpoint what is meant by social change in the relevant literature but this is not easy since the concept is often used in extremely loose fashion in discussions of law as though it were self-explanatory.' 
and Ladinsky define 'social change' (I take 'social change' and 'transformation' as synonyms, perhaps mistakenly) as 'any nonrepetitive alteration in the established modes of behaviour in society,. ${ }^{46}$ If patterns of social relations and established social norms and social roles change, 'social change' occurred. ${ }^{47}$ Grossman and Grossman prefer a wider definition of 'social change' and identify varying levels or orders of change. ${ }^{48}$ They identify (a) an alteration in individual patterns of behaviour; (b) an alteration in group norms or relational patterns between individuals and groups and between groups; (c) an alteration in patterns of relationships between individuals or groups to the political, economic or social system; and (d) an alteration in a given society's 'basic values' ${ }^{49}$ Chemerinsky simply states that 'social change connotes an overall noticeable effect on society. ${ }^{50}$ Morison's definition is more explicit. He defines social change as 'a fundamental alteration in the way an aspect of society is structured, in the way that people relate to one another or in the way that an issue is perceived and acted upon,. ${ }^{51}$

More recent commentaries on what 'transformation' entails, specifically in the South African context, are more helpful. In the context of transformative constitutionalism, Klare sees a highly egalitarian, caring, multicultural community, ${ }^{52}$ while Albertyn and Goldblatt talk of a 'complete restructuring of the state and society, including a redistribution of power and resources along egalitarian lines, the eradication of systemic forms of domination and material disadvantage and the development of opportunities which allow people to realise their full human potential within positive social relationships. ${ }^{53}$ Pieterse understands the concept as 'mandating the achievement of substantive equality and social justice, the infiltration of human rights norms into private relationships and the fostering of a 'culture of justification' for every exercise of public power'. ${ }^{54}$ At the serious risk of oversimplifying these authors' views, it seems as if 'transformative' laws, specifically in the context of present day South Africa, may be seen as laws that attempt to do one or both of the following:

LM Friedman \& J Ladinsky 'Social Change and the Law of Industrial Accidents' (1967) Col LR 50 .

47 Cotterrell (note 45 above) 47.

48 JB Grossman \& MH Grossman Law and Change in America (1971) 4.

49 Ibid 6.

50 E Chemerinsky 'Can Courts Make a Difference?' in N Devins \& DM Douglas (eds) Redefining Equality (1998) 191, 198. At the same page he states that clear criteria for assessing or measuring social change do not exist.

51 J Morison 'How to Change Things with Rules' in S Livingstone \& J Morison (eds) Law, Society and Change (1990) $5,7$.

52 KE Klare 'Legal Culture and Transformative Constitutionalism' (1998) 14 SAJHR 146, 150.

53 C Albertyn \& B Goldblatt 'Facing the Challenge of Transformation: Difficulties in the Development of an Indigenous Jurisprudence of Equality' (1998) 14 SAJHR 248, 249.

54 M Pieterse 'What do We Mean When We Talk about Transformative Constitutionalism?' (2005) 20 SAPL 155. The alleviation of concrete hardship, the socio-economic upliftment of the majority of South Africans and the achievement of social justice are integral components of constitutional transformation in his view. 
(a) Transformative laws aim to create a more egalitarian society where socioeconomic disparities between different communities are eradicated or at least softened. In the shorter term such laws would aim at the proportional representation across income, wealth and resource categories of the various social groupings, and in the longer term would aim at a society where all residents will lead dignified lives, free from hunger and want. ${ }^{5 .}$

(b) Such laws aim to change the 'hearts and minds' of the broader South African community so that racism, sexism, homophobia, xenophobia and the like become anathema. ${ }^{56}$

There is a clear overlap between the goals of transformative legislation, and some of the suggested goals of anti-discrimination legislation as referred to above. $^{57}$

I would suggest that both these 'types' of transformation may be identified from various provisions in the Act.

As to the achievement of a thorough-going readjustment in income distribution and unemployment rates, the Preamble of the Act speaks of the "eradication of social and economic inequalities, especially those that are systemic in nature, which were generated in our history by colonialism, apartheid and patriarchy', as well as 'systemic inequalities and unfair discrimination' that 'remain deeply embedded in social structures [and] practices'. This, in turn, 'implies the advancement, by special legal and other measures, of historically disadvantaged individuals, communities and social groups who were dispossessed of their land and resources'. Section 2(g) contains as one of the objects of the Act, 'to set out measures to advance persons disadvantaged by unfair discrimination'. When applying the Act, it must be done in such a manner as to give effect to 'the Constitution, the provisions of which include the promotion of equality through legislative and other measures designed to protect or advance persons disadvantaged by past and present unfair discrimination ${ }^{58}$ Section 4(2) of the Act contains the following directive (my emphasis):

In the application of this Act the following should be recognised and taken into account:

(a) The existence of systemic discrimination and inequalities, particularly in respect of race, gender and disability in all spheres of life as a result of past and present unfair discrimination, brought about by colonialism, the apartheid system and patriarchy; and

(b) the need to take measures at all levels to eliminate such discrimination and inequalities.

Albertyn \& Goldblatt (note 53 above) 249; Pieterse (note 54 above) 159; D Moseneke 'The Fourth Bram Fischer Memorial Lecture: Transformative Adjudication' (2002) 18 SAJHR 309, 316; S Liebenberg 'The New Equality Legislation: Can it Advance Socio-Economic Rights?' (2000) 2 ESR Review 2; Bohler-Muller \& Tait (note 26 above) 407.

56 Cf D Brand 'Die Wet op die Bevordering van Gelykheid en die Voorkoming van Onbillike Diskriminasie' (2000) Autumn Word and Action 13; Moseneke (note 55 above); BA Hocking 'Where are We After 10 Years of Discrimination Law?' (1995) 15 Proctor 19, 21; Y Dror 'Law and Social Change' (1958) 33 Tul L Rev 787, 788; Klare (note 52 above) 150.

57 Also cf Gutto (note 44 above) 7 where he refers to 'social legislation'.

58 Section 3(1)(a); my emphasis. 
Sections 7, 8 and 9 of the Act contain examples of the kinds of discrimination the legislature had in mind when the Act was drafted. Some of these examples very clearly have a socio-economic transformation in mind, notably ss 7(d), 7(e), 8(c), 8(e), 8(g), 8(h), 8(i), and 9(c).

It is clear from an analysis of a number of provisions in the Act that the legislature also hoped to bring about changes in the 'hearts and minds' of South Africans with the enactment of this Act. The Preamble implicitly expresses the wish that the Act will remove the 'pain and suffering' brought 'to the great majority of our people', as well as the 'systemic inequalities and unfair discrimination' that 'remain deeply embedded in social structures, practices and attitudes, ${ }^{59}$ and that the Act will restore people's lost dignity. The Preamble explicitly notes that 'this Act endeavours to facilitate the transition to a democratic society, united in its diversity, marked by human relations that are caring and compassionate.$^{60}$ A number of the examples listed in ss 7 and 8 at least implicitly addresses attitudinal discrimination. ${ }^{61}$ The sections in the Act dealing with the promotion of equality also at least implicitly engage anticipated attitudinal changes. ${ }^{62}$

\section{(c) The establishment of accessible enforcement mechanisms}

The Act also clearly has as one of its goals the establishment of forums where discrimination disputes may be raised and resolved. A number of provisions in $\mathrm{s} 2$ (which contains the objects of the Act) may be read to create this aim. Section 2(b)(i) states that the Act aims at giving effect to the letter and spirit of the Constitution, in particular 'the equal enjoyment of all rights and freedoms by every person. ${ }^{63}$ This subsection anticipates a procedure whereby individual claimants will be able to ensure the enjoyment of their human rights. Section 2(b)(iv) contains another object of the Act: 'the prevention of unfair discrimination and protection of human dignity as contemplated in sections 9 and 10 of the Constitution'. This subsection, read with ss 2(d), 2(f), 4(1)(b), 16 and the regulations to the Act, ${ }^{64}$ make it very clear that the Act aims at the creation of inexpensive, accessible, informal dispute resolution mechanisms (equality courts).

\section{(d) Why the Act will fail in facilitating transformation}

As discussed in section II above, the drafters of the Act took the typical defects of a court-driven dispute resolution mechanism into account and as a result the Act creates the (currently untapped) potential for wide-ranging court-driven societal transformation. 
However, some of the Act's underlying assumptions are unrealistic or false. The Act implicitly assumes that the equality courts will address at least a significant number of incidents of discrimination effectively - how else will real transformation take place ${ }^{65}$ For example, consider clause $4(c)$ of the Schedule to the Act, in terms of which the legislature targets unfair discrimination in the provision of housing bonds, loans or financial assistance on the basis of race, gender or other prohibited grounds. Assume that a bank's lending policy has the effect of disproportionately denying loans to black applicants. If only a few applicants approach the courts, that bank may very well settle each of the few individual cases. A bank will likely only consider changing its policy if a large number of applicants who have been denied a loan approach an equality court. If a particular individual is an avowed racist, the Act will only reach him if a particular defendant approaches a court to complain. His behaviour will likely only change once he has been sued and it becomes too expensive to be a racist. (More promisingly, the Act allows claims to be brought as class actions ${ }^{66}$ or as public interest actions, ${ }^{67}$ but this potential remains untapped, arguably because of the complexities involved in bringing a class action, and the high threshold established for a public interest action by the Constitutional Court. $^{68}$ )

From a socio-legal perspective, the Act will also struggle to achieve its stated purpose of facilitating societal transformation. A number of authors' views on the role of law in a given society complement each other. Whether one distinguishes between 'simplex' and 'multiplex' relationships, ${ }^{69}$ or propose that 'law varies inversely with other social control', ${ }^{\text {, }}$ or distinguishes between a 'Gemeinschaft' and 'Gesellschaft' conception of society, ${ }^{71}$ or talks of a continuum ranging from intimacy to open hostility, ${ }^{72}$ the same pattern emerges: The closer a particular society mirrors a close-knit, co-dependent, 'happy (or unhappy) family', the smaller the role that (official state) law will play. ${ }^{73}$ To this one could add authors' observation that neutral and instrumental areas of life may to a degree be controlled by law, but that 'areas of emotion'

This seems to have been the viewpoint of at least one of the drafters of the Act. On page 6 of the 'draft project plan' drafted by the Chief Director: Transformation and Equity and the Chief Director: Legislation in the Department of Justice and Constitutional Development (copy of document in my possession), it was estimated that 1.5 million people would use the dispute resolution mechanisms established in terms of the Act in the first year of operation (my emphasis).

66 Section 20(1)(c)

67 Section 20(1)(d).

68 Lawyers for Human Rights $v$ Minister of Home Affairs 2004 (4) SA 125 (CC) read with Ferreira v Levin NO 1996 (1) SA 984 (CC) para 234.

69 RL Kidder Connecting Law and Society: An Introduction to Research and Theory (1983) 70-2.

70 D Black The Behavior of Law (1976) 6-7.

71 F Tönnies Community and Society (Gemeinschaft und Gesellschaft) (2002) 37-102; E Kamenka \& AE Tay 'Social Traditions, Legal Traditions' in E Kamenka \& AE Tay (eds) Law and Social Control (1980) 3, 8-11.

72 LL Fuller 'Human Interaction and the Law' in KI Winston (ed) The Principles of Social Order: Selected Essays of Lon L Fuller (1981) 211, 237

73 Cf Galanter (note 9 above) 130. 
are extremely difficult to direct. ${ }^{74}$ This does not bode well for an Act that was inter alia drafted to address the intimate spheres of life. ${ }^{75}$

Consider just one example of the Act's likely impotence. It is at least arguable that a society will only change if the basic relationships in a society change: For example, as long as the division of labour within a household is skewed in favour of men, real substantive equality between the sexes will not be achieved. But it is precisely here that the Act will most probably fail most spectacularly. Although the Act may in theory arguably intrude into the home and perhaps may assist a wife who wishes to sue her husband for failing in his role as a sensitive, caring, burden-sharing companion, ${ }^{76}$ it is extremely unlikely to happen. Such a claim faces a number of hurdles. The loving wife will probably not realise that a potential claim lies against her errant husband. The clerk of the equality court may turn the complainant away, perhaps even laugh in her face. The presiding officer may dismiss the claim as frivolous and award a punitive costs order against her. Even if a far-reaching remedy is awarded, an unsympathetic husband will likely laugh off the claim and she will be forced to institute another action, or have him thrown in jail for contempt of court, whereafter divorce could follow (which is perhaps what she should have done in the first place, without first wasting money on a case that may well be dismissed as frivolous). And if only a few wives should follow the equality court-route, even assuming that their husbands will adhere to far-reaching court orders, other wives' position will remain unchanged. ${ }^{77}$

In a 'society' of about 40 million inhabitants consisting of banks and lenders, insurance companies and insured, farmers and labourers, shopkeepers and customers, restaurants and clients; African chiefs and their subordinates; schools and learners, universities and students, employers and employees, it is the powerful 'repeat players' that will likely come out on top and it is likely that

74 Morison (note 51 above) 8; N Luhmann A Sociological Theory of Law (1985) 243; Cotterrell (note 45 above) 24; CAA Packer Using Human Rights to Change Tradition: Traditional Practices Harmful to Women's Reproductive Health in Sub-Saharan Africa (2002) 150.

75 Cf C Albertyn, B Goldblatt \& C Roederer (eds) Introduction to the Promotion of Equality and Prevention of Unfair Discrimination Act 4 of 2000 (2001) 4.

76 My example is not absurd. Section 8(d) of the Act outlaws 'any practice, including traditional, customary or religious practice, which impairs the dignity of women and undermines equality between women and men, including the undermining of the dignity and well-being of the girl child'. A Sen 'Normative Evaluation and Legal Analogues' in JN Drobak (ed) Norms and the Law (2006) 247, 254 argues that these kinds of obligations should not be legislated: '[I]n a male-dominated traditionalist society ... the social recognition of a wife's 'human right' to be consulted in family decisions may be a very important move. But it does not follow that a human right of this kind should be put into the rule books through legislation — perhaps with the husband being arrested, locked up, or otherwise punished by the state if he were to fail to consult his wife'.

77 J Gardner 'Private Activities and Personal Autonomy: At the Margins of Anti-Discrimination Law' in B Hepple \& EM Szyszczak (eds) Discrimination: The Limits of Law (1992) 148, 149 puts it more eloquently: if we see 'social life' as state-family-market, then law has almost nothing to do, as it is a weapon of the 'state' sphere only; as 'economic and personal activities are generally assumed to be organized so that they can look after themselves'. When courts are relatively reluctant to intrude in the market and the family, how does one call into question long-established patterns of domination internal to such activities? In other words, most people cannot be atomistic, rational 'authors of their own lives'. 
the 'one-shotters' will lose more than they win. ${ }^{78}$ In dependent (or multiplex) relationships, such as farmer-labourer, it is extremely unlikely that courts will be utilised. ${ }^{79}$ And in simplex relationships, it is likely that a potential claimant will decide to walk away from a potential lawsuit, inter alia because of the material and emotional costs involved.

The Parliamentary hearings process relating to the finalisation of the Act partly bears out this argument. The most vociferous opponents of the Bill were the insurance and banking industries - arguably well-informed, wellresourced 'repeat players' that may be expected to be sued often. ${ }^{80}$ These organisations are also involved in 'instrumental' or 'neutral' areas of life, where law may be expected to play a larger role. The lobbyists for the 'oneshotters', the likely plaintiffs, argued in favour of the removal of barriers to lessen the strategic disadvantage they would face in giving life to the Act. ${ }^{81}$

At first blush authors such as Chemerinsky and Budlender seem to come to a different conclusion and seem to be much more positive about the potential effect of utilising the law. Chemerinsky ostensibly argues that courts 'make a difference' and that changes in the law lead to changes in society. ${ }^{82}$ However, a careful reading of his argument reveals that he has a very narrow definition of what would constitute 'effective' court action. He seems to argue that an anti-discrimination Act would be effective if it provides redress to injured individuals. ${ }^{83}$ He uses tort law as an example: Tort law is effective because it compensates innocent victims, although it may not deter dangerous products and practices. ${ }^{84}$ He takes solace from Brown v Board of Education because it was an 'enormously important' statement of equality, although it had little effect. $^{85} \mathrm{He}$ argues that court cases upholding the (American) Constitution protects key values and therefore have 'great social importance' even if no social change flows from the cases. ${ }^{86} \mathrm{He}$ correctly argues that categorical statements about the (lack of) ability of courts to achieve social change must

In an empirical study completed in 2005 it was shown that from 1994 to 2004, approximately 930 275 farm labourers and their dependents were illegally evicted from farms. The study concluded that only about one per cent of evictions that occurred after 1997 were performed in terms of the relevant legislation. In six out of seven cases the farm workers had no legal representation when their eviction case was heard in court. Sake24 (Beeld) (19 March 2007) 12. This finding is not surprising from a socio-legal perspective.

79 It is at least arguable that vulnerable groups are more likely to be caught up in multiplex (dependent) relationships and therefore more likely not to utilise courts.

80 For example, see Gutto (note 44 above) 108-9.

81 A number of bodies argued for the inclusion of further prohibited grounds in the Act, such as HIV/AIDS, family status and family responsibility, socio-economic status and nationality (AIDS Law Project; Commission on Gender Equality; Gender Project, Community Law Centre; National Coalition for Gay and Lesbian Equality). See also the submissions of The Equality Alliance.

82 Chemerinsky (note 50 above) 191-203.

83 Ibid 193; my emphasis.

84 Ibid 193.

85 At 198-9 Chemerinsky is quite candid about Brown's failure. A decade after Brown only 1.2 per cent black schoolchildren were attending school with whites and in present day America racial separation is increasing. 
be avoided, ${ }^{87}$ but he does not provide a single example of a court case that has led to social change. If anything, he provides examples where courts have frustrated social change. ${ }^{88}$ Budlender optimistically refers to Minister of Health v Treatment Action Campaign (No 2) ${ }^{89}$ as an example where court action successfully led to changes in government policy and the provision of treatment to (poor) people living with $\mathrm{HIV} .{ }^{90}$ But in another decision by the Constitutional Court relating to socio-economic rights, Government of the Republic of South Africa $v$ Grootboom, ${ }^{91}$ very little happened in its aftermath. Three years passed before the national government put in place an emergency housing programme that to date has not been adequately implemented. ${ }^{92}$ Budlender argues that to be effective, civil society organisations must pressurise government to comply with court orders and the public media must pursue the particular matter. ${ }^{93}$ This translates to enormous organisational ability, energy, effort and money; something most litigants, including civil society organisations, do not have.

Dror is probably correct: Law seems to be the quickest and cheapest way in changing a society and that is why governments too readily turn to the law when it wishes to dispose of a social ill. ${ }^{94}$ In this belief governments are probably usually mistaken. ${ }^{95}$

It should be clear then that I accept that this article has a very modest and very limited purpose: The Act will likely not achieve its stated goals of establishing a more caring or more equal South African society. On the other hand, for those individual claimants so inclined, a potentially very powerful tool has been created to address insular, discrete instances of unfair discrimination. Put differently, the second goal of anti-discrimination legislation referred to above - the establishment of forums where discrimination complaints may be aired and resolved - has been achieved. However, due to inelegant drafting, a number of provisions in the Act do not provide the degree of protection to claimants as it may have done, had the Act been drafted more carefully. The remainder of this article identifies some of the gaps in the Act that could frustrate (individual) meritorious complaints.

I will now proceed to suggest specific amendments to the Act. Where I suggest specific changes to the Act, one of the main considerations that I kept in mind was that the drafters of the Act anticipated that ordinary citizens may have wished to utilise this Act without consulting a lawyer. ${ }^{96}$ The Act should therefore be as explicit and user-friendly as possible regarding the elements of

90 G Budlender 'Implementing Judgments on the Positive Obligations of States' (2006) 15 Interights Bulletin 139, 140.

912001 (1) SA 46 (CC).

92 Budlender (note 90 above) 139.

93 Ibid 139-140.

94 Dror (note 56 above) 802.

95 Ibid.

96 Cf ss 2(e), 4(1)(a), 4(1)(b) \& 4(1)(c), and the regulations issued in terms of the Act. 
the causes of action created in the Act. It is of no benefit to ordinary South Africans that courts have crafted exceptions and extensions to what is stated in the Constitution or legislation regarding equality. From the perspective of creating an accessible enforcement mechanism, it is therefore better to explicitly confirm a particular rule or principle in legislation than to argue that the particular rule or principle has already been established in a particular court case.

\section{The Definition of 'Discrimination'}

The Act defines 'discrimination' as 'any act or omission, including a policy, law, rule, practice, condition or situation which directly or indirectly - (a) imposes burdens, obligations or disadvantage on; or (b) withholds benefits, opportunities or advantages from, any person on one or more of the prohibited grounds. ${ }^{97}$

Sensibly, the definition of discrimination in the Act makes it clear that courts must consider the effect of the impugned conduct or omission. To avoid any uncertainty, the words 'whether intentionally or not' could have been added to the definition. ${ }^{98}$ Protection against retaliation should expressly be added to the Act. ${ }^{99}$ The definition of discrimination should make it clear that discrimination will be found to exist even if discrimination on a particular ground was not the sole or main reason for the discriminatory act or omission. ${ }^{100}$ A provision should also be added to the Act to the effect that anyone who causes, encourages or requests another person to do or refrain from an act that amounts to discrimination in terms of the Act, should be held to have discriminated as if in their personal capacity. ${ }^{101}$ A section expressly incorporating the principles relating to vicarious liability should further be added. ${ }^{102}$

98 This was suggested in a definition of 'discrimination' in a suggested alternate Bill presented by the Women's Legal Centre and the Social and Economic Rights Project, Community Law Centre, University of the Western Cape (UWC) to the ad hoc Parliamentary committee. Section 20(4) of the Northern Territory Anti-Discrimination Act provides that ' $[\mathrm{T}]$ he motive of a person alleged to have discriminated against another person is, for the purposes of this Act, irrelevant'.

99 Section 13(1) of the Yukon Human Rights Act contains a prohibition against retaliation relating to harassment. The Act could be amended to include the following section: 'No person may retaliate or threaten to retaliate against an individual who objects to the discrimination'. See also IDASA's submission to the ad hoc Parliamentary committee which suggested a provision protecting participants from negative consequences as a result of using the Act.

100 Bailey \& Devereux (note 5 above) 315. Section 20(3)(a) of the Northern Territory AntiDiscrimination Act provides that '[F]or discrimination to take place, it is not necessary that the attribute is the sole or dominant ground for the less favourable treatment'. However, Brink v Kitshoff NO 1996 (4) SA 197 (CC) para 43 states that '[i]t is sufficient that the disadvantageous treatment is substantially based on one of the listed prohibited grounds, namely sex' (my emphasis). The equality court in Pillay v MEC for Education, KwaZulu-Natal 2006 (6) SA 363 (EqC) para 21 held that disadvantageous or harmful or prejudicial treatment must primarily be based on one of the prohibited grounds.

101 Cf Bailey \& Devereux (note 5 above) 301.

102 Section 133(1) of the Queensland Anti-Discrimination Act provides that ' $[\mathrm{I}] \mathrm{f}$ any of a person's workers or agents contravenes the Act in the course of work or while acting as agent, both the person and the worker or agent, as the case may be, are jointly and severally civilly liable for the contravention, and a proceeding under the Act may be taken against either or both'. See also s 10 of the Manitoba Human Rights Code. The Black Sash's submission to the ad hoc Parliamentary committee suggested that a section similar to s 60 in the Employment Equity Act be added to the Bill. 
A number of authors are critical about the wording of $\mathrm{s} 14 .^{103}$ The section should probably be redrafted to distinguish between 'State discrimination' and 'private discrimination', and between 'discrimination' and 'differentiation,. ${ }^{104}$

\section{The List of Prohibited Grounds}

I would argue that s 14 - the test for unfairness — is the heart of the Act. It would then not be of particular moment to establish that 'discrimination' had occurred, as the Act only prohibits 'unfair' discrimination. The only work the list of prohibited grounds in s 1(1)(xxii) does is to distinguish between 'differentiation' and 'discrimination'. For example, to pay a higher insurance premium for a red motor vehicle compared to a white vehicle (assuming that insurance companies' databases illustrate that red cars are proportionately involved in more collisions than any other colour of vehicle) amounts to mere differentiation, as 'vehicle colour' is not listed as a prohibited ground. Paying a higher premium because the usual driver of the vehicle will be young, or male, would amount to discrimination as 'age' and 'sex' are listed as prohibited grounds. The list of grounds could then be seen as a gatekeeper of sorts, to distinguish between cases worthy of a full enquiry into the fairness or unfairness of distinguishing on particular grounds, and cases not worthy of such an enquiry.

As long as the list of grounds performs this gate-keeping task, it would then seem to follow that the list may be broadened without losing the Act's focus. Expressly including additional grounds makes a complainant's work a little easier because one or more of the requirements listed in s 1(1)(xxi)(b) read with s 13(2)(b) then need not be established. To this end, the grounds listed in s 34 of the Act (HIV/AIDS status, ${ }^{105}$ nationality, socio-economic status, family responsibility and family status) should be expressly added to the list of prohibited grounds.

In the context of an Act that was inter alia drafted to facilitate a large-scale redistributive programme, it is particularly peculiar that 'socio-economic status' was not added explicitly as a prohibited ground. ${ }^{106}$ Where an Act has been drafted to effect societal transformation, one would have expected the legislature to follow through on its promise and to explicitly provide that a claim may be brought based on socio-economic status discrimination, or to put it more plainly, based on discrimination against the poor. Liebenberg and

103 For criticism of s 14, see Albertyn et al (note 75 above) 41 and further. G Carpenter 'Equality and Non-Discrimination in the New South African Constitutional Order (4): Update' (2002) 65 THRHR $177,182-3$ argues that ss 14 (f)-(i) are inappropriate in the context of private or domestic relationships and that this should have been better set out in the Act.

104 See Kok (note 29 above) 62-5 where the distinction between 'differentiation' and 'discrimination' is discussed in the context of insurance.

105 Despite the directive in the Act that the Equality Review Committee had to within a year of its establishment make a recommendation to the Minister regarding the s 34 grounds, no such formal recommendation had been made by $2006<$ http://www.pmg.org.za/viewminute.php?id=8330>.

106 It appears that cabinet decided that the additional grounds, including HIV status and socio-economic status, should not be given explicit recognition in the Act. Albertyn et al (note 75 above) 81 . 
O'Sullivan are quite modest in their appraisal of what the inclusion of socioeconomic status as prohibited ground may achieve: ${ }^{107}$

Where poverty is a major barrier to women enjoying access to socio-economic rights such as decent health care, housing and education, socio-economic status as a prohibited ground can facilitate challenges to these structural exclusions. While it is recognised that legislation alone cannot eliminate the inequalities inherent in a market-based economy, it can at least seek to combat the exclusion of the poor from social goods, services and facilities arising from irrational prejudices and stereotyping.

The authors provide an example of what they have in mind: The inclusion of the ground could be used to combat the notion that all rural women or women living in informal settlements are bad credit risks and so should automatically be excluded from consideration for bank loans. ${ }^{108}$ They leave open their own more pertinent question: Can the inclusion of socio-economic status as prohibited ground facilitate substantive challenges to the material disparities existing within and between groups? ${ }^{109}$ The authors suggest that the definition of socio-economic status in the Act hints at a more substantive content but that all will depend on the development and application of the unfairness enquiry in relation to the ground of socio-economic status. At this stage too few equality court judgments have been reported to even attempt a guess at how progressive the equality courts will be in their interpretation of socioeconomic discrimination cases. Consider an example Liebenberg provides: In the South African market economy a number of public services are in the process of being privatised. If market-related prices for 'commodities' such as water will be charged, poverty may well lead to a large number of people not being able to enjoy access to this crucial right. ${ }^{110}$ Will courts characterise such instances as unfair discrimination? They may very well decide that market-generated inequalities are instances of reasonable discrimination, which would partly destroy the transformative potential of the inclusion of this ground. ${ }^{111}$

107 S Liebenberg \& M O’Sullivan 'South Africa's New Equality Legislation: A Tool for Advancing Women's Socio-economic Equality?', paper presented at a conference titled 'Equality: Theory and Practice in South Africa and Elsewhere', held at the University of Cape Town from 18 to 20 January 2001 , copy of paper in author's possession, page 32 of the paper; my emphasis.

108 Ibid. K Reddy 'The Equality Clause in the South African Bill of Rights and Accessible Credit for Disadvantaged Communities' (2002) TSAR 674 argues in similar vein. At 686 he suggests that the use of the following loan criteria amounts to indirect race discrimination: geographical area; collateral; authenticated proof of income; operation of bank account; ability to produce banking details; amount requested above minimum set by the lending institution. These criteria would also amount to direct discrimination based on socio-economic status and is an easier argument to make than indirect race discrimination.

109 Liebenberg \& O’Sullivan (note 107 above) 32; my emphasis.

110 Ibid 7. Also see Liebenberg (note 55 above) 4 for the same argument.

111 Liebenberg \& O’Sullivan (note 107 above) 37. Parghi (note 18 above) 137 is extremely forthright. The author considers the suggestion that 'social condition' be added as a prohibited ground to the Canadian Human Rights Act and concludes at 170 that 'adding this new ground would not prevent the market from discriminating against poor people who are truly unable to pay for goods such as housing or food ... Social condition would therefore not effect the degree of social change that some of its proponents expect it to and that some of its opponents fear it will'. 
If one considers that ordinary South Africans will not likely make much sense of the 'test' for recognising additional grounds, ${ }^{112}$ it may be helpful to have as complete a list of prohibited grounds as possible contained in the Act. In addition to the s 34 grounds, the following grounds may also be considered for explicit inclusion in the list of prohibited grounds. This suggested list is by no means exhaustive. The suggested grounds listed below were sourced from Australian and Canadian legislation. Other jurisdictions' anti-discrimination laws may well contain further grounds: actual or presumed association with a person who has, or is believed or presumed to have, an attribute referred to in the list of prohibited grounds; ${ }^{113}$ breastfeeding; ${ }^{114}$ criminal record; ${ }^{115}$ irrelevant criminal record; ${ }^{116}$ irrelevant medical record $;{ }^{117}$ parenthood $;{ }^{118}$ physical appearance, ${ }^{119}$ political belief, opinion, association, affiliation or activity; ${ }^{120}$ same-sex partnership status; ${ }^{121}$ source of income or status as recipient of social welfare payments; ${ }^{122}$ and trade union or employer association activity. ${ }^{123}$

The definition of 'prohibited grounds' should also be amended to make it clear that presumed membership of these grounds will also constitute a cause of action. A number of foreign anti-discrimination Acts contain such provisions. $^{124}$

112 Section 1(1)(xxii)(b) of the Act.

113 Section 19(1)(r) Northern Territory Anti-Discrimination Act; s 6(l) Yukon Human Rights Act; s 5(1) (v) Nova Scotia Human Rights Act; s 6(m) Victoria Equal Opportunity Act; s 7(1)(m) Queensland Anti-Discrimination Act.

114 Section 19(1)(h) Northern Territory Anti-Discrimination Act; s 6(ab) Victoria Equal Opportunity Act; s 7(1)(e) Queensland Anti-Discrimination Act. Section 1(1)(xix) defines pregnancy as including 'any condition related to pregnancy' which could be read to include breastfeeding, but on a strict literal interpretation would not fit this definition as breastfeeding occurs after the pregnancy has run its course.

115 Section 6(i) Yukon Human Rights Act.

116 Section 19(1)(q) Northern Territory Anti-Discrimination Act.

117 Section 19(1)(p) Northern Territory Anti-Discrimination Act.

118 Section 19(1)(g) Northern Territory Anti-Discrimination Act; s 6(ea) Victoria Equal Opportunity Act. The Act defines 'family responsibility' in s 1(1)(xi) as 'responsibility in relation to a complainant's spouse, partner, dependent, child or other members of his or her family in respect of whom the member is liable for care and support', which could be read to include parenthood.

119 Section 6(f) Victoria Equal Opportunities Act; M Pieterse 'Discrimination Through the Eye of the Beholder' (2000) 16 SAJHR 121

120 Section 19(1)(n) Northern Territory Anti-Discrimination Act; s 6(j) Yukon Human Rights Act; s 1(d) Prince Edward Islands Human Rights Act; s 5(1)(u) Nova Scotia Human Rights Act; s 6(g) Victoria Equal Opportunity Act; s 7(1)(j) Queensland Anti-Discrimination Act.

121 Sections 1, 2 and 3 Ontario Human Rights Code.

122 Section 1(d) Prince Edward Islands Human Rights Act; ss 2 and 3 Ontario Human Rights Code; s 5(1) (t) Nova Scotia Human Rights Act; s 4(b) Alberta Human Rights, Citizenship and Multiculturalism Act.

123 Section 19(1)(k) Northern Territory Anti-Discrimination Act; s 6(c) Victoria Equal Opportunity Act; s 7(1)(k) Queensland Anti-Discrimination Act.

124 For example, s 8 of the Queensland Anti-Discrimination Act: 'Discrimination on the basis of an attribute includes direct and indirect discrimination on the basis of (a) a characteristic that a person with any of the attributes generally has; or (b) a characteristic that is often imputed to a person with any of the attributes; or (c) an attribute that a person is presumed to have, or to have had at any time, by the person discriminating; or (d) an attribute that a person had, even if the person did not have it at the time of the discrimination'. Section 9(1)(a) of the Manitoba Human Rights Code defines 'discrimination' as 'differential treatment of an individual on the basis of the individual's actual or presumed membership in or association with some class or group of persons, rather than on the basis of personal merit'. 


\section{Systemic Discrimination}

The discussion under this heading is linked to the analysis relating to the prohibited ground of socio-economic status above.

The Act does not contain a clear, explicit recognition of systemic discrimination as a separate, self-standing cause of action. I have in mind the explicit, up-front legislative recognition of particular, named, structural barriers in society and particular, named respondents, ${ }^{125}$ put on notice to address these barriers or to face court action. Delgado argues that a single plaintiff — single defendant court case 'reinforces a perpetrator perspective that sees racism as a series of isolated actions and not an integrated system that elevates one group at the expense of another, ${ }^{126}$ Day argues in similar vein that an anti-discrimination system that is modelled on a dispute resolution system assumes that if the particular form of inequality is serious enough the victim will complain. ${ }^{127}$ Such a system also assumes that, broadly speaking, society is equal and only the lapses from equality will be complained of and remedied by law. ${ }^{128}$ Delgado asks that a search should begin for 'broad structures that submerge people of color, workers, and immigrants, and replace these structures with ones that can fulfill our unkept promises of democracy, equality, and a decent life. ${ }^{129}$ He seems to implicitly argue that the way to attain a system of 'economic democracy', as he terms it, would be to take the battle to 'the streets, ${ }^{130}$ If one still has some faith in the legal process, as I do, another option would be to stretch the legal options as far as they can go. One such 'stretch' would be the explicit recognition of a justiciable claim based on systemic discrimination. MacDonald argues that liberal democracies draw political disputes into institutions where these disputes are contained: 'Disputes are localized, particularized, insulated: particular grievances do not metastasize into general indictments of the whole social order, ${ }^{131}$ On the other hand, a generous, wholehearted application of the principle of substantive equality and the recognition of a claim based on systemic discrimination may well lead to an 'indictment of the whole social order'.

The following provisions in the Act may be identified as possibly hinting at the existence of an independent claim based on systemic discrimination that is, a claim not based on the private law model of a single plaintiff versus a

125 S Fredman Discrimination Law (2002) 174 argues that discrimination law that seeks to transform a society should adhere to a model of 'structural reform'. While in the orthodox dispute resolution model the defendant would be the wrongdoer and the provider of the remedy, in the structural reform model the defendant would be the body best able to achieve the required reform.

126 R Delgado 'Two Ways to Think about Race: Reflections on the Id, the Ego, and other Reformist Theories of Equal Protection' (2001) 89 Geo LJ 2279, 2295.

127 S Day 'Impediments in Achieving Equality' in LM Martin \& KE Mahoney (eds) Equality and Judicial Neutrality (1987) 402, 403.

128 Ibid. At $402 \mathrm{n} 1$ Day argues that 'discrimination because of race, sex, and disability is now understood by all serious scholars in the field not as isolated acts of individuals but as deeply etched patterns in [North American] society, rooted in history, and embedded in the ordinary practices of all our institutions'.

129 Delgado (note 126 above) 2296.

130 Delgado (note 126 above) 2296

131 M MacDonald Why Race Matters in South Africa (2006) 170. 
single defendant, litigating about a singular, discrete wrong; but rather a claim based on group-experienced, structural harm:

- The definition of 'equality' in s 1(1)(ix), which speaks of 'de facto equality' and 'equality of outcomes'.

- The 'test' for the recognition of further prohibited grounds not listed in the Act, which includes the requirement that such a ground must 'cause or perpetuate systemic disadvantage'. ${ }^{132}$

- The definition of 'socio-economic status', which refers to structural barriers faced by the poor in South Africa. ${ }^{133}$

- The objects of the Act, which include to give effect to the equal enjoyment of all rights and freedoms by every person, ${ }^{134}$ and to give effect to the promotion of equality. ${ }^{135}$

- When equality courts adjudicate disputes arising from the Act, the principle of the use of corrective or restorative measures in conjunction with deterrent measures should be applied. ${ }^{136}$

- When the Act is applied, the existence of systemic discrimination and inequalities, ${ }^{137}$ and the need to take measures at all levels to eliminate such discrimination and inequalities, ${ }^{138}$ should be recognised and taken into account.

- Section 7(d), which refers to the 'provision or continued provision of inferior services to any racial group, compared to those of another racial group'.

- Section 8, which contains a number of examples of systemic or structural discrimination based on sex or gender: gender-based violence; ${ }^{139}$ female genital mutilation; ${ }^{140}$ the system of preventing women from inheriting family property; $;^{141}$ any policy or conduct that limits women's access to land rights, finance and other resources; ${ }^{142}$ conduct that limits women's access to social services and benefits; ${ }^{143}$ and the systemic inequality of access to opportunities by women as a result of the sexual division of labour. ${ }^{144}$

- Section 9, which contains one example of systemic discrimination based on disability: the failure to eliminate obstacles that limit or restrict disabled people from enjoying equal opportunities or the failure to take steps to reasonably accommodate the needs of disabled people. ${ }^{145}$

132 Section 1(1)(xxii)(b)(i).

133 Section 1(1)(xxvi): 'a social or economic condition or perceived condition of a person who is disadvantaged by poverty, low employment status or lack of or low-level educational qualifications'.

134 Section 2(b)(i).

135 Section 2(b)(ii).

136 Section $4(1)(d)$.

137 Section 4(2)(a).

138 Section 4(2)(b).

139 Section 8(a).

140 Section 8(b).

141 Section 8(c).

142 Section 8(e).

143 Section 8(g).

144 Section 8(i).

145 Section 9(c). 
- Section 14(3)(e), which requires an equality court to consider if the impugned discrimination was systemic in nature or not.

- The Act allows the institution of representative claims, ${ }^{146}$ class actions, ${ }^{147}$ and public interest actions. ${ }^{148}$

- A number of the remedies listed in the Act require a respondent to over time make structural adjustments in order to remove structural barriers. ${ }^{149}$

- The Schedule to the Act contains a number of examples that could be termed as systemic or structural discrimination. ${ }^{150}$

Alas, on closer reading these sections read together do not amount to the recognition of a cause of action of systemic or structural discrimination. (I analyse the bulleted points above seriatim.) The mere fact that the word 'equality' as used in the Act is given a broad meaning does not create a right and only defines the ambit of the word. Similarly, s 1(1)(xxii)(b)(i) does not create a cause of action and merely defines the range of prohibited grounds contemplated by the Act's drafters. The fact that socio-economic status is given a broad meaning still begs the question whether this ground will be recognised by equality courts. Furthermore, a claim based on socio-economic status need not be a systemic discrimination case. ${ }^{151}$ Sections 7, 8 and 9 list examples and are explicitly made subject to the general prohibition against discrimination in s $6 .^{152}$ Section 6 does not explicitly refer to systemic discrimination. Section 14(3)(e) seems to indicate that systemic discrimination would more likely be unfair, but would not automatically lead to the conclusion that all cases of systemic discrimination are by its very nature unfair, let alone lead to the recognition of a general claim of systemic discrimination. Representative claims, class actions and public interest actions based on discrimination will not necessarily be systemic discrimination cases. The list of practices in the Schedule of the Act, some of which amount to systemic discrimination, is in terms of s 29 of the Act a list of possible examples in terms of which a claim may be brought and may not be unfair in a particular case. ${ }^{153}$ A claim based on the examples in ss 7-9 or the Schedule would still have to be brought in terms of the general prohibition against discrimination in s 6 of the Act, read with the test for unfairness as set out in s 14 of the Act. It appears then that the drafters opted for the 'soft' enforcement of cases of systemic discrimination,

146 Section 20(1)(b).

147 Section 20(1)(c).

148 Section $20(1)(d)$.

149 Section 21(2)(g); s 21(2)(h); s 21(2)(i); s 21(2)(k); and s 21(2)(m).

150 Clause 4(b); 4(c); 8(a); and 9(b).

151 An indigent single parent may approach an equality court because his child may have been turned away from school for failure to pay her school fees. The fact that many such cases may exist does not turn that specific equality court case into a systemic discrimination matter, it would still be a single plaintiff versus a single defendant with a potentially positive outcome for a single litigant.

152 Albertyn et al (note 75 above) 56.

153 Section 29 reads that the Schedule contains practices 'which are or may be unfair' (my emphasis). If a practice 'may be' unfair, it may also be fair in a given case. 
primarily by requiring mainly public bodies to promote equality (and not to be taken to court for failing to do so)..$^{154}$

Should a general claim based on systemic discrimination be read into the Act, it would pose particularly strenuous challenges to civil society and rights groups. In particular cases it may be difficult to identify the breach of the equality right; it may lie in 'inadequate budgetary allocations, capacity deficits (particularly at provincial and local government level), unduly complex regulations, a lack of knowledge by disadvantaged groups of their rights, and inadequate infrastructure'. ${ }^{155}$ The identification and addressing of such barriers to full equality would require 'careful empirical research combined with a detailed understanding of the context of service delivery. ${ }^{156}$

\section{REMEDIES}

This discussion is linked with IV above, as the type of remedies associated with systemic discrimination would usually differ from 'once off' cases of discrimination.

Lacey argues in favour of the recognition of what she terms 'remedial rights. ${ }^{157}$ These rights would emphasise socio-economic disadvantage and the distribution of basic goods and would primarily apply to groups who are currently exposed to disadvantage based on present or past effects of discrimination. ${ }^{158}$ The remedy associated with the enforcement of such rights would be to order that positive and effective steps be taken to combat and overcome the effects of the discrimination within a reasonable time. ${ }^{159}$ Properly resourced public agencies would enforce the rights and would also monitor the effectiveness of the remedies over time. ${ }^{160}$ Possible remedies would then include urban development programmes, educational reforms, and the award of money to set up various community projects. ${ }^{161}$ She envisages that courts would be involved in the enforcement of these rights and that it would not be left to the political process to give effect to these rights. ${ }^{162}$ Lacey's suggestions are vague in that it is unclear what the content of these programmes and reforms would be. Her

154 Although the Act contains a number of provisions that seem to create promotional obligations, the section of the Act dealing with enforcement (s 21) seems only to be concerned about unfair discrimination, hate speech and harassment, which are the causes of action that may be brought to an equality court. An equality court seems not to have the power to for example declare that the State or a particular body has failed in its duty to promote equality, or to hold the relevant official in contempt for failing to promote equality in the prescribed manner.

155 Liebenberg \& O'Sullivan (note 107 above) 8.

156 Ibid. Also see Parghi (note 18 above) 147: '[C]omplex empirical evidence is often necessary to demonstrate that equality-hindering attitudes and norms have actually resulted in unequal conditions ... A second difficulty ... is that expert evidence may be required to analyze the quantitative evidence, explain the assumptions underlying it, assist the tribunal in drawing inferences from it, and scrutinize competing quantitative evidence'.

157 Lacey in Hepple \& Szyszczak (note 5 above) 113.

158 Ibid.

159 Ibid.

160 Ibid 114.

161 Ibid.

162 Ibid. 
argument also suffers from a middle-class perspective as it is unclear which remedies would be granted if the disadvantaged group approaching a court would be unskilled, homeless and unemployed. It is difficult to imagine what a legal system could offer to such groups.

The Act contains a number of provisions that seem to foreshadow what Lacey has in mind: ss $7(\mathrm{~d}),{ }^{163} 8(\mathrm{e}),{ }^{164} 8(\mathrm{~g}),{ }^{165}$ and $8(\mathrm{i}) .{ }^{166}$ However, these provisions appear to amount to examples only, ${ }^{167}$ do not constitute separate causes of action and are expressly made subject to the general prohibition against unfair discrimination. Ideally these examples should be given the status of separately enforceable rights and should be expanded. Appropriately tailored research would have to be undertaken to identify structural barriers in different contexts.

\section{The Respondent's DeFEnCES}

Even if it is argued that the list of factors in s 14 is not closed and that it would be open to any equality court to consider any relevant argument in favour of the complainant or respondent, this section would benefit from legislative amendment.

Section 20(3)(a) of the Northern Territories Anti-Discrimination Act provides that discrimination is still present even if the prohibited ground was not the sole or dominant ground for the discrimination. A similar provision could be added to the Act. ${ }^{168}$

Serious consideration should be given to deleting s 14(2)(c) from the Act. ${ }^{169}$ This section was added to the Act after intense lobbying from the banking and insurance sectors during the Parliamentary hearings to have a clause added to the Act that would have operated as a complete defence for so-called 'commercial differentiation'. ${ }^{170}$

For example, the Banking Council argued that 'the Bill as currently formulated would preclude banks from using appropriate systems and mechanisms to arrive at sound judgments on the provision of banking services and products

163 'The provision or continued provision of inferior services to any racial group, compared to those of another racial group'.

164 'Any policy or conduct that unfairly limits access of women to land rights, finance, and other resources'.

165 'Limiting women's access to social services or benefits, such as health, education and social security'.

166 'Systemic inequality of access to opportunities by women as a result of the sexual division of labour'.

167 Kok (note 29 above) 305; Albertyn et al (note 75 above) 56.

168 However see the caveat in note 100 above.

169 'Whether the discrimination reasonably and justifiably differentiates between persons according to objectively determinable criteria, intrinsic to the activity concerned'.

170 Professors Albertyn, Gutto and Liebenberg graciously allowed me to make copies of their personal files relating to the drafting of the Act. A large portion of these files consisted of copies of the various bodies and institutions' submissions made to the ad hoc Parliamentary committee who held public hearings on the Act during from November 1999 to January 2000. I relied on the contents of these copied files in preparing the summaries of these submissions that follow below. Copies of these files are in my possession. 
to appropriate customers, markets and segments, based on objective commercial principles and criteria'. It suggested that a defence be built into the Act for 'credit criteria, products and services that are based and applied solely on commercial principles and criteria'. Business South Africa (BSA) also called for a defence applying to the insurance, health, banking and other services sectors, namely, 'that differentiation based on objective actuarially and commercially based evidence should not be regarded as unfair discrimination, as is the case in other countries. ${ }^{171}$

The Financial Services Board (FSB) noted that it is widely accepted in foreign jurisdictions that 'differentiation on sound underwriting principles and actuarial grounds' does not constitute unreasonable discrimination.

The Institute of Retirement Funds of Southern Africa argued that 'sound financial operation of a retirement fund depends (generally) on differentiations based on actuarial grounds. If funds are constrained from applying these traditional risk management techniques, the result will be a general erosion of the level of member benefits and the hastened demise of defined benefit funds in particular'. It argued that 'reasonable and bona fide differentiation based on actuarial or statistical data should be excluded from categorisation as "unfair discrimination","

The Life Offices' Association's (LOA) submission was in similar vein, and went further to suggest that 'any legislation which directly (or indirectly) prohibits non-arbitrary differentiation founded on proper risk assessment constitutes a threat to the very existence of the Insurance Industry and millions of policyholders, ${ }^{172}$ In a letter sent to the Minister of Justice on 25 Janury 2000, the LOA proposed that a new clause 14(2) be inserted into the Act:

It is not unfair discrimination to differentiate between persons or groups of persons according to reasonable and justifiable criteria which are objectively determinable and intrinsic to the activity concerned.

In general, it seemed to be the intention of the pro-business groups to have a provision added to the Act that would have allowed banks and insurers to 'discriminate' on particular grounds. However, their submissions only refer to 'differentiation'. ${ }^{173}$ In terms of Constitutional Court jurisprudence, 'differentiation' occurs if a distinction is made on a ground not protected by the equality clause. ${ }^{174}$ A provision in the Act that would have merely provided that discrimination is not unfair if it amounts to differentiation would therefore have been rather pointless. Although earlier drafts of the Bill seemed to adopt

171 BSA adopted the following alarmist approach: 'The Bill effectively compels the providers of insurance, banking and health services to ensure that all persons are provided with services and does not allow differentiation on reasonable and objective actuarial and commercial grounds'. BSA did not appreciate that differentiation on grounds not listed in the Bill, i.e. 'commercial' grounds, was not dealt with in the Bill.

172 My emphasis.

173 Only the South African Insurance Association's submission clearly stated that 'discrimination' by an insurer should in particular circumstances be excused.

174 Pretoria City Council v Walker 1998 (2) SA 363 (CC) para 35. 
this route, ${ }^{175} \mathrm{~s} 14(2)(\mathrm{c})$ makes it clear that the issue is 'discrimination' — that is, differentiation on a prohibited ground.

As a result, instead of a complete defence for commercial discrimination, the Act now contains an additional factor to be considered in the overall assessment of whether the discrimination was fair or unfair. It would appear that the section intends to convey the meaning that if the discrimination reasonably and justifiably differentiates on the basis of objectively determinable criteria and intrinsic to the activity concerned, such discrimination would more likely be fair. Albertyn et al interpret s 14(2)(c) so as to give extra weight to 'properly construed commercial considerations within the overall context of the section as a whole'. ${ }^{176}$ Liebenberg ${ }^{177}$ and Liebenberg and O'Sullivan ${ }^{178}$ are concerned that this section could undermine substantive socio-economic equality, as this section invites courts to find that market-related service fees and costs are reasonable and justifiable differentiation. If Parliament is serious about sending a message to the equality courts that this Act is primarily a driver for socio-economic transformation, s 14(2)(c) should be deleted to remove any doubt as to where the emphasis should lay when considering the factors listed in s 14 .

If one takes a rigorous approach to what 'fairness/unfairness' and 'reasonableness/justifiability' entails, the scheme set out in s 14 does not adhere to constitutional jurisprudence on the approach to be followed when deciding whether discrimination was fair or unfair. When dealing with a law of general application that unfairly discriminates, a court must further consider whether that unfair discrimination in nevertheless reasonable and justifiable. When the discrimination does not occur in the form of a law of general application, an enquiry into reasonableness and justifiability is not made. The Act does not make this distinction and subjects all enquiries to an assessment of fairness/ unfairness, ${ }^{179}$ and reasonableness and justifiability. ${ }^{180}$ Strictly speaking the Act should also have followed a three-stage approach: (a) did discrimination occur; (b) if so, was the discrimination unfair; (c) if so, was the discrimination reasonable and justifiable. However, this could have made s 14 even more complex to interpret and to apply to concrete factual situations. Ultimately, an equality court must decide if the discrimination complained of was legitimate or not; whether one calls it 'fair' or 'reasonable' discrimination is not necessarily of any moment.

175 See for example Clause 8(b) of a draft Bill marked 'E5' and dated 14 January 2000 which states that 'It is not unfair discrimination to ... (b) differentiate between persons according to reasonable, justifiable and objectively determinable criteria that are intrinsic and inherent to economic or other legitimate activity.'

176 Albertyn et al (note 75 above) 47.

177 Liebenberg (note 55 above) 5 .

178 Liebenberg \& O'Sullivan (note 107 above) 36-7.

179 Sections 14(2)(a), 14(3)(a), 14(3)(b), 14(3)(c), 14(3)(d) and 14(3)(e).

180 Sections 14(2)(c), 14(3)(f), 14(3)(g), 14(3)(h) and 14(3)(i). 


\section{The Equality Courts}

Section 21(2)(o) of the Act currently provides that an equality court may grant an appropriate order of costs against any party to the proceedings. This open-ended, unguided discretion should be curtailed. The Act should contain explicit directions as to how this discretion is to be exercised. The general rule should be that each party should bear her own costs, particularly when the complainant is unrepresented, barring frivolous cases and when it is manifestly clear that the court process is being abused. ${ }^{181}$

Section 21(2)(p) provides that an equality court may grant an order that any provision of the Act must be complied with, but does not expressly grant an equality court the power to mero metu initiate contempt of court proceedings against a recalcitrant litigant. ${ }^{182}$ In terms of the usual principles relating to contempt of court, if a respondent disobeys a court order, the complainant would have to approach the court that granted the original order, ${ }^{183}$ and then show on notice of motion that an order was granted against the respondent, that the respondent was either served with the order or informed of its contents, and that he either disobeyed it or neglected to comply with it. ${ }^{184}$ In terms of the procedure allowed in the equality courts, this cumbersome process would be anomalous. Equality courts are expressly allowed to retain jurisdiction over a matter even after judgment had been obtained. Equality courts are for example empowered to order a respondent to implement special measures to address unfair discrimination, ${ }^{185}$ and to order a respondent to make regular progress reports to the court regarding the implementation of the court's order. ${ }^{186}$ If a respondent does not obey a court order that expects continuing observance and where an equality court has retained jurisdiction, it should be open to that court to initiate contempt of court proceedings of its own accord. ${ }^{187}$

\section{CONCLUSION}

It has been argued often that law has little to offer when combating discrimination. ${ }^{188}$ How then do I justify this article, which concerns proposed

181 Also see A Henderson 'Show Me the Money! Damages and Costs in Constitutional Cases and Challenging the Rules in 'Normal' Proceedings' (1999) February De Rebus 25.

182 The Centre for Public Law and the Judge Institute of Management Studies, University of Cambridge prepared a report in which these institutions proposed a fourth generation anti-discrimination law for the United Kingdom. One of its recommendations was that the equality tribunal should have the power to certify a failure to comply with a tribunal order to the High Court for contempt of court proceedings, or to itself award a monetary penalty (my emphasis) - Zimmer (note 10 above) 259.

183 James $v$ Lunden 1918 WLD 88; SA Druggists Ltd v Deneys 1962 (3) SA 608 (E).

184 Consolidated Fish Distributors (Pty) Ltd v Zive 1968 (2) SA 517 (C); Höltz v Douglas \& Associates (OFS) CC 1991 (2) SA 797 (O).

185 Section 21(2)(h).

186 Section $21(2)(\mathrm{m})$.

187 However $S v$ Mamabolo 2001 (3) SA 409 (CC) paras 51-9 probably stands in the way of such an amendment to the Act.

188 See DA Bell 'Brown v Board of Education and the Interest-Convergence Dilemma' (1980) 93 Harv LR 518, 523; Delgado (note 126 above) 371; Handler (note 14 above) 105-18; Dickens (note 5 above) 285-7; Bailey \& Devereux (note 5 above) 308; McKenna (note 6 above) 325 . 
amendments to the Equality Act? This Act was drafted to concretise s 9(4) of the Constitution and one of its aims is to eradicate unfair State and private discrimination. ${ }^{189}$ Why do I turn to law if law is likely to fail?

Discrimination law only 'fails' if a particular question is asked. That question is: 'Can law solve the problem of discrimination?' and the answer is 'No'. If one asks if law can provide effective redress for aggrieved individuals, ${ }^{190}$ the answer may well be yes, at least for some individuals some of the time. Where equality courts have been established in terms of the Act, aggrieved complainants may approach these courts and may without legal representation lodge a claim by completing a document at the court, ${ }^{191}$ whereafter the clerk of the court will have this document served on the respondent. At the trial, an unrepresented litigant may be assisted by a presiding officer, who is entitled to approach the matter in a quasi-inquisitorial fashion. ${ }^{192}$ If a complainant in a discrimination matter establishes a prima facie case of discrimination, it falls to the respondent to persuade the court that the discrimination was fair. ${ }^{193}$ However, the Act contains a number of problematic provisions that may hamper a complainant's quest for effective relief. This article was therefore directed to pointing out how the Act may be improved to prevent (at least some) litigants from falling through the cracks, as it were. ${ }^{194}$

189 See s 2(c) of the Act.

190 Cf Lustgarten (note 42 above) 467. Joachim (note 40 above) 57 argues that an anti-discrimination Act has four goals: 'correcting persistent patterns of discrimination against protected groups, preventing discrimination before it occurs, acting as spokesperson on issues related to discrimination; and when discrimination does occur, providing an effective, expeditious remedy through a fair process' (my emphasis). Also see the discussion in section III of this article.

191 The regulations to the Act pertaining to the prevention of unfair discrimination were published in the Government Gazette on 13 June 2003 (note 64 above). The regulations require equality court clerks to provide assistance to disabled, illiterate and unrepresented litigants. Where a complainant is unrepresented, the clerk of the equality court is supposed to step into the breach and fulfil the role of a pseudo-paralegal (see clause 5 of the relevant Regulations).

192 The regulations explicitly attempt to create informal courts where substance is supposed to triumph over technicality. The regulations also envisage active, interventionist presiding officers who may dispense with the ordinary court rules and ordinary time limits in effecting justice (for example clause 8 of the relevant Regulations).

193 Section 13, and see Kok (note 29 above).

194 Lacey (note 5 above) 121 is forthright in her views: '[W]e simply cannot afford to abandon the legal process ... because in the real world disadvantaged people do not always have a choice about whether or not to defend or advance their needs and interests by legal means. Sometimes they simply have to do so because legal action is initiated by other parties, and on other occasions they have to because no other avenue of redress is available or remains to be explored. We must try to alter law so as to make it more receptive to the arguments of the powerless ...' (my emphasis). At 124 n42 she agrees with KW Crenshaw 'Race, Reform, and Retrenchment: Transformation and Legitimation in Antidiscrimination Law' (1988) 101 Harv LR 1331 that 'rights discourse is sometimes the only available point of entry for struggle or reform, and that we need to use liberal legal ideology pragmatically, with our eyes open to its dangers'. 